\title{
Tanulmányok
}

\section{METAFORÁK EGY TUDOMÁNYÁG TELJESÍTMÉNYÉRŐL}

\section{METAPHORS FROM THE SOCIOLOGY OF VALUES}

\author{
Bodor Tamás', Varga Károly² \\ ${ }^{1}$ PhD, Associate Professor of Communication, University of Wisconsin-Stevens Point \\ Tamas.Bodor@uwsp.edu \\ ª szociológiatudomány doktora, professor emeritus, Pázmány Péter Katolikus Egyetem \\ var9184@iif.hu
}

\begin{abstract}
ÖSSZEFOGLALÁS
Négy metafora segítségével vállalkozunk az értékszociológia mint középszintű tudományág fél évszázados történetéből olyan teljesítményeket bemutatni, amelyek tudományos újdonságuk mellett jelentős társadalmi-politikai hatással is bírtak, illetve bírnak. Az első: Herkules, a kígyóölő csecsemő arra utal, hogy az 1960-as években az értékszociológia már első hónapjaiban a kommunista Magyarországon milyen mitikus erőbravúrt: ideológiai tabutörést volt képes végrehajtani. A második: csábítás a legvidámabb barakkban, annak leleplezése, ahogyan a szovjet blokk országai közül - katasztrofális eladósodásból - nálunk virágzott a nemzeti eszmei tartásból az elvtelen hedonizmusba való átcsábítás. A harmadik: védőháló vagy függőágy, azt vizualizálja, hogy a segélyezési rendszer preferálása helyett a munkaalapú társadalom kiépítése milyen karikírozó megjelenítésben ábrázolhatja az öngondoskodásra való motiváltság meggyengülését. A negyedik: gyümölcsöstál vagy turmixolt gyümölcslé, a földrészek egyenlőtlen gazdasági fejlödésének 21. századi kiegyenlítődési változataira utal, és ahelyett, hogy a kollektív és maszkulin katonakultúráknak a már az individuális és feminin értékek irányába fejlődött nyugati társadalomba való beözönlését helyeselné, a perspektivikus megoldást inkább abban látja, hogy a gazdagabb civilizáció nyújtson segítséget az eredeti helyükön eredeti épségükben megmaradó kultúráknak.
\end{abstract}

\section{ABSTRACT}

The half a century old sociology of values is a discipline of the middle ranges. From its history with the help of four metaphors we present some discoveries that has not only offered new insights at the time but still have enduring social-political implications. First, Hercules the snake killer infant refers to the early time of the sociology of values as the young discipline was capable of breaking ideological taboos in the communist Hungary of the 1960s. Second, temptation in the happiest barrack reveals how in debt-stricken Hungary, the nation's principled character was replaced by unprincipled hedonism. Third, safety net or hammock describes how efforts to replace a system of welfare-dependency with a work-oriented society may be impeded by 
weakened motivation for self-reliance. Four, fruit basket or fruit juice mix refers to processes of equalizing global economic development in the $21^{\text {st }}$ century that follows the era of unequal development across the continents. Instead of celebrating the advance of collectivistic/masculine military cultures within individualistic/feminine-value oriented Western societies, the metaphor offers an alternative: wealthy civilizations should provide assistance to other cultures so they may be preserved intact in their original places.

Kulcsszavak: metafora, értékszociológia, tabutörés, konzumhedonizmus, liberális és konzervatív értékek, migráció

Keywords: metaphor, sociology of values, taboo breaking, consume-hedonism, liberal and conservative values, migration

A cikket Wacha Imre emlékének ajánljuk

A metaforák ${ }^{1}$ tudományos jelentőségéről a szenior szerzőt (V. K., 1930-) Geert Hofstede győzte meg legfontosabb kutatási eredménye, a „kultúrák digitális világtérképe" heurisztikus erejével, melynek segítségével elvégezte a magyar értékrendszer „földrajzi helymeghatározását” (Varga, 1986); a tanítványát (B. T., 1972-) pedig a legbefolyásosabb metaforateoretikus, George Lakoff, akinek té-

${ }^{1}$ Cikkünk első kulcsfogalma a metafora, amit azon túl, hogy a mindennapi nyelvhasználat szerves részét képezi, kognitivista értelmezésben mint világlátásunkat és konceptualizációnkat befolyásoló fogalmi eszközt használunk, amelynek segítségével képesek vagyunk absztrakt cselekvések és tartalmak konkrét módon való kifejezésére. Ám mielőtt e müveletre rátérnénk, egyikünk újabb dolgozatából (Varga, 2017) felidézünk egy ihlető erejével mindkettőnket mélyen érintő metaforát, amely mind a szekuláris vallástudományban, mind a teológiában a legsúlyosabb problémák egyikeként számon tartott „relativizmus vagy fundamentalizmus” dilemmában kínál arany középutas megoldást. A 20. század egyik legjelentősebb ökumenikus teológusa, Karl Rahner közismert „anonim kereszténység” fogalmának újabb keletü finomításáról van szó, amit szerzője (Knauer, 2011) a rahneri 'inkluzivizmus' helyett az 'interiorizmus' fogalmával címkéz:

„Az interiorizmus szerint a keresztény üzenet más vallásokhoz való viszonyát ahhoz lehetne hasonlítani, hogy ezek, mint ama kövek, amelyek bizonyos fényforrás hatására fluoreszkálnak, azaz úgy villannak fel, mintha a fény a saját bensőjükböl jönne. Az ilyen kövek már eleve rendelkeznek azzal a tulajdonsággal, hogy fluoreszkálni képesek, ám e tulajdonságuk csak egy megfelelő hullámhosszú fényforrás által nyilvánulhat meg." (Knauer, 2011, 17.)

E megkapó költői metafora talán a témakör legelöremutatóbb megoldási kísérlete. Ugyanakkor szociológusként meg kell jegyeznünk, hogy bár a katolikus egyházi hagyomány exkluzivista álláspontjához képest előbbre lépést jelent, de az érintettek ezt is bekebelezőnek érezhetik, vagyis apologetikai vagy missziós célokra éppúgy használhatatlan, mint az anonim kereszténység tana. 
teleit szembesítette a World Value Survey rendszeréből nyert empíriával. ${ }^{2}$ Közös tanulmányunkban négy bevilágítónak érzett metaforával érzékeltetjük az értékszociológia középszintủ tudományág néhány társadalmilag előrevivőnek vélt teljesítményét.

\section{ELSŐ METAFORA: HERKULES, A KÍGYÓÖLŐ CSECSEMŐ}

A hazai értékszociológia mint középszintü elmélet az újszülöttként kígyót ölő Herkuleshez hasonlatosan már élete első hónapjaiban mitikus erőbravúrt felmutató akadémiai diszciplína lett, amikor a „létezett szocializmus” hivatalos ideológiai-kultúrpolitikai rendszerében „tabutörést” volt képes végrehajtani. Jelen beszámolónk keretei között még futó áttekintést sem adhatunk arról, hogy az eszmetörténeti jelentőségű kezdet utáni bő fél évszázadban (1963-tól napjainkig) az értékszociológia még milyen „hidrát, vadkant, háromfejű kutyát ölt meg és

${ }^{2}$ Míg Hofstede metaforáira itteni említésükön túl már csak egy további vonatkozásban utalunk, a Lakoff-féle metaforáknak cikkünk központi fejezetét szenteljük. Ami Hofstede „kulturális világtérképének” ökológiai faktorelemzéssel nyert „földrajzi koordinátáit” illeti, ezek mint „hosszúsági és szélességi körök” ( $\boldsymbol{x}$-tengely: Hatalmi távköz, $\boldsymbol{y}$-tengely: Bizonytalanságkerülés) markáns metaforákkal címkézett térnegyedekben helyezik el az egyes országok értékrendszerét. Így kerültek a mindkettőben alacsony, „lezser” angolszászok a „Falusi piac”, az európai és dél-amerikai újlatinok a mindkettőben magas „Emberpiramis”, az ázsiaiak az $\boldsymbol{x}$-en magas, $\boldsymbol{y}$-on alacsony „Család”, a németek-osztrákok-izraeliek-finnek pedig az ennek fordítottjában a „Jól olajozott gép" metaforájával jelölt térnegyedbe. Mi, magyarok a Hofstede-battériával felszínre hozott látens jellemzőink alapján ez utóbbiban találtuk magunkat (ami meglepetést keltett, mivel csak alaposabb reflektálásra nyújtott evidenciaélményt).

${ }^{3}$ A ,középszintű elmélet” Bacon utáni újrafelfedezése és a szociológiában uralkodó paradigmaként való elfogadtatása Robert K. Merton (1980) nevéhez füződik, aki meg tudta győzni a tudományág művelöinek zömét arról, hogy ,a szociológia akkor képes fejlődni, ha föleg középszintü elméleteket próbál kidolgozni, s akkor marad el a fejlődésben, ha elsősorban totális szociológiai rendszerek kialakítására törekszik" (Merton, 1980, 104.). - Ám amikor az 1960-as évek közepétől a Szovjetunióban is elindultak az empirikus társadalomvizsgálatok (Simirenko, 1966), várható volt, hogy ennek képviselői (például: G. Oszipov, R. Jovcsuk, A. G. Zdravomiszlov, V. A. Jadov stb.) saját ortodoxiájuk igazolására olyan érvelésbe kezdtek, amit Hegedűs András, az MTA Szociológiai Kutatócsoport alapító igazgatója ,apologetikus szociológiának” nevezett (Hegedűs, 1988).,Jól ismert Merton véleménye - írja Oszipov és Jovcsuk -, mely szerint a szociológia még nem elég érett egy egységes és átfogó elmélet kidolgozására, s hogy csak néhány, az absztrakció közbülső szintjén elhelyezkedő elméletük van. Ez nem alkalmazható a marxizmus tudományos szociológiájára, melyet elöször Marx dolgozott ki, immár 125 évvel ezelőtt, s amely kiállta az idő próbáját." (Simirenko, 1966) Ehhez képest első értékszociológus szerzőnk, Charles Morris (1956) rendszere már szót sem vesztegetett a marxizmus hasonnevű kategóriájának nagyon is szűk, csupán „,pol-gazd” relevanciájára, hanem a saját középszintű elméletével és metodikájával végzett nemzetközi UNESCO-vizsgálatot, amelybe bekapcsolódva mi is újat és érvényest tudtunk mondani ifjúságunk értékrendszeréről. 
istállót takarított ki”, viszont úgy tűnik, épp jelenlegi teljesítménye - úgymint a világmigráció liberális versus konzervatív értelmezésének és ebből fakadó stratégiáiknak mérlegre tevése - különös figyelmet érdemel, amelynek eredményét további metaforáinkban villantjuk fel.

Már az első metaforában tükröződő teljesítményhez Szelényi Ivánt hívjuk tanúnak, de a későbbiekben is vele diskurzusban (tehát itt-ott vitában) közöljük eredményeinket. Szelényi (2018) ugyanis miután az 1956 utáni amnesztia évéből, 1963-ból három „faltörő kost” említ: Szalai Sándort, Szántó Miklóst és Hegedűs Andrást, akik „,megpróbálták bizonygatni, hogy a szociológiának marxista változata is lehetséges", velük szemben az MTA-intézet két olyan alapító tagját nevezi meg - a nemrég elhunyt Szesztay Andrást és Varga Károlyt -, akik már kialakult református-evangelikális, illetve katolikus-újskolasztikus szemléletükkel aligha járulhattak hozzá az új tan marxista ortodoxiájának megőrzéséhez. Így az alapítók túlélöjeként - András halála után Márkus Marisával és Nemes Ferenccel már csak hárman maradtak -, Varga Károly idézheti fel, milyen müveletekben zajlott e történészi szemmel „tabutörésnek” látott fordulat. Nevezetesen mivel a marxista szociológia a dialektikus materializmus filozófiai tanának a társadalomra történő alkalmazása, vagyis a „tört-mat” volt - amit viszont olyan metaforák uraltak, mint „,a mennyiségi változások minőségibe való átcsapásának” képzete (annak példáján láttatva, hogy az egyre több hỏ adagolásával a víz egyszerre csak gőzzé válik), és bár e „törvényszerüség” társadalmi forradalmat magyarázó ereje az ezt magoló egyetemisták számára hihetőnek tủnhetett, ám empirikus kutatás vezérlésére aligha volt alkalmas -, ezért az értelmes kutatói munkához égetően szükség lett a nyugati szociológia „empíriát elemző kategóriáinak” honosítására. Kulin Ferenc a Magyar Mủvészetben megjelent tanulmánya, A szociológia esélyei $(2017,3$.$) erre így emlékezik:$

„A kezdet egy marxista-leninista ideológiai tabu megtörése volt, amely az értékfogalom politikai-gazdaságtani használatán (használati érték, csereérték) kívül tiltotta a »burzsoá áltudományként« aposztrofált szociológiának (Fedoszejev-tankönyv) »idealista« elemző kategóriáját. A tabutörés természetesen nem mehetett végbe intézményi támogatás nélkül. Ezt a Hegedűs András által az MTA kebelében megalakított Szociológiai Kutatócsoport nyújtotta... Az ideológiai tabutörést Varga Károly neve jelzi. Neki sikerült először (1963-ban) feltérképeznie és nemzetközi összehasonlításba vonnia a magyar egyetemi ifjúság értékrendszerét, öt egyetem csaknem ezer hallgatójának mintáján. Róla írta Szelényi Iván (2014): »Két-három évtizeddel megelőzte a mai szociológiában uralkodóvá váló 'kultúrszociológiai' megközelítést. Ennek lényege, hogy nem a társadalmi struktúrából magyarázzák a kultúrát (ez volt az, amit a kultúra szociológiájának neveztünk), hanem a kultúrából értelmezik a társadalmi struktúrát (ezért értékszociológia vagy kultúrszociológia). Ezt az elméleti 
megközelítést Jeffrey Alexander [Szelényi Yale egyetemi kollégája] vezette be a 90-es évek közepén; őt Varga majd három évtizeddel előzte meg.ı"

A nyugatról importált empirikus értékszociológiának itt csak futó utalásban említhető első eredményei mellett - amilyen például annak felfedezése, hogy a magyar egyetemi ifjúság a lengyelhez képest erősebben individualista, és ezzel az USA egyetemista mintájához közelít, amit Hankiss Elemér tíz évvel később a „steril individualizmus" leletével igazolt vissza - sajnos egy restellni való mellékterméke is lett. Ez pedig épp az aczéli kultúrpolitika hírhedté vált 3T formulája, aminek kétes dicsőségében így osztoznia kell az értékszociológia honosításának is. Amikor ugyanis Varga (1965) Clyde Kluckhohntól átvette a Morris-féle értékdimenziók (apollói, prométheuszi, dionüszoszi, krisztusi, mohamedán, buddhista, maitreyán) eltérő erősségű preferenciáinak jelölésére a domináns, variáns, deviáns értéktipológiát mint a „többség által elfogadott” versus „egyes csoportoknál tolerált" versus ,a többség által elvetett” értékek áttekintését, rá pár hónapra megjelent az MSZMP KB Kulturális és Elméleti Munkaközösségének tanulmánya Az irodalom, a müvészetek és a társadalmi izlés címen, illetve az ezt kibontó kommentárcikkek, amelyekből az derült ki, hogy Magyarországon ez a „többség” a hatalmi monopólium diktátumainak pártos követése, a „türelem” egyes ,haladó polgári” szerzőknek nyújtott ajándék, a „deviáns” pedig a vonaltól elhajló szemlélet. Így a legegyszerűbb értékszociológiai elemző kategóriából a durván átpolitizált, bár kedélyesen alliteráló Tá-Tü-Ti lett. Amivel mintha a tabutörésért kívánt volna revansot venni a kultúrpolitika. (Mindez persze nem nyílt sisakos harcban zajlott, hiszen deklaráltan mindannyian azonos oldalon álltunk.)

Ám a megállíthatatlan olvadás (a nemzetközi dégèle) már e hármas osztás kontúrjait is ellazította, és a szociológiában a „tört-mat”-nak már csak utóvédharcra futotta. Megjelentek a nyugati mértékkel is mérhető empirikus projektek, például a Szalai Sándor szervezte kelet-nyugati időmérleg kutatás, ahol magyar részről Cseh-Szombathy László, Ferge Zsuzsa és Varga Károly (1973) olyan empíriából modelleztek, amely köszönő viszonyban sem volt a szocialista társadalom „,munkás-paraszt-értelmiség" struktúrájának dogmájával.

\section{MÁSODIK METAFORA: CSÁBÍTÁS A LEGVIDÁMABB BARAKKBAN}

Tanulmányunk e második fejezetében szintén Szelényi Iván eszmefuttatásából indulhatunk ki, miután ő és Varga Károly 2018 tavaszán A magyar szociológia az ezredfordulón címü, a Wesley János Lelkészképző Főiskolán tartott rendezvénysorozaton - részben ellentétes irányokból közelítve - fejtették ki nézeteiket a magyar társdalom politikai-ideológiai jelenéről és várható alakulásáról, mind- 
ketten az értékorientációs mélystruktúrák szempontjából. A liberalizmus témájában a lényeget Szelényi is az individualizmus versus közérdek viszonyában ragadja meg. Varga értelmezése pedig egy olyan gondolati ívet vázolt fel, amely az individualizmus konzumhedonista változatának Daniel Bell $(1976,1996)$ általi elemzésétől Kulin Ferenc (1994) legvidámabb barakk értelmezéséig terjedt. Bell szerint a hedonizmus mögött a hit megrendülése áll. S míg Japánban a háborúvesztés, a Szovjetunióban Sztálin büneinek beismerése okozott ilyen hitbeli összeomlást, addig az USA-ban: „maga az establishment tagadja meg saját intézményeinek legitimitását, föleg az a fiatal rétege, melynek normálisan az elit pozíciójába kellene belenőnie. E válság legfőbb következménye a civitas elvesztése, vagyis azé a spontán indíttatásé, hogy álljunk ellen a kisértésnek, hogy a közjó rovására magunk gazdagodjunk. A civitas veszendőbe menetele pedig vagy azt jelenti, hogy az érdekek annyira polarizálódnak, hogy terrorizmus és csoportharcok robbannak ki, vagy azt, hogy minden közéleti interakció cinikus eljárássá válik, melyben a legtöbb hatalommal bírók nyerészkednek a gyengék rovására."

S előzményként Bell azt említi, hogy a Benjamin Franklin-féle puritanizmus ideológiájának elpárolgása után a tömeghedonizmust az 1920-as évektől a mozival és a rádióval hajszolták, amelyek a leghatalmasabb magatartásformáló erönek, a reklámnak lettek közvetítő eszközei: „A jelenkori Amerika legfeltünőbb tevékenysége az eladás lett, ami a takarékosság, mértékletesség, igénytelenség helyett a pazarlásra buzdított. A takarékosság a protestáns etika szíve. A '60-as évek végére viszont a bankok keményen reklámozták készpénz-kölcsönzési szolgáltatásaikat, amikkel ügyfeleik sok ezer dollárral »nyújtózhattak túl takarójukon «. A fogyasztó elcsábitása beteljesedett." (Bell, 1976, 1996)

Ugyanezt, a hosszú távú takarékosság helyett a rövid távú fogyasztás szenvedélyét tételezte az egy évtizeddel ezelőtt kipattant amerikai eredetủ gazdasági világválság értékrendszeri tényezőjének Geert Hofstede (Hofstede G.-Hofstede G. J., 2008) is. Kimutatta, hogy a kínai kultúrának épp a globalizáció szempontjából releváns specifikuma, a hosszú távú orientáció az, amivel behozhatatlan előnyben van az amerikai társadalommal szemben.

Magyar viszonylatban pedig e konzumhedonizmus ellenállhatatlan „csáberejét", illetve ennek az életveszélyes eladósodásból történő manipulatív felhasználását a „legvidámabb barakk” értékszociológiai értelmezésével Kulin Ferenc (1994) leplezte le. „Sikerült elhitetni a tömegekkel, hogy a dollármilliókkal megvásárolt lojalitásuk a nemzeti egység záloga, s hogy ez a fajta egység pedig a szocialista értékek megvalósulásának biztosítéka. A manipuláció eredményességének titka nyilvánvalóan az volt, hogy nem közvetlenül a tudatra, az érzelmekre, a nemzeti önérzetre irányult - mint a Rákosi korszak ideológiai egységteremtő kísérletei -, hanem a hétköznapi közérzetet vette célba. S ily módon sikerült a köztudatban »lefokozni« a nemzeti érzület minden olyan mozzanatát, amely az anyagi értékek- 
kel való árukapcsolás lehetősége nélkül »pusztán « a szolidaritás élményére, vagy más erkölcsi és szellemi készségekre alapozódott."

Mi más ez, mint a Bell által felpanaszolt civitásvesztés kispályás változata? Ám Kulin arra is felfigyelt, hogy e dollármilliós eladósodással fedezett konzumközérzet „szitáján” a rendszerváltás elött egyetlen társadalmi csoport, az alkotó humán értelmiség látott át (és volt képes neki szervezetten ellenállni). E fontos belátások nyomán tehát „, a liberalizmus kijavítása”4 nem megtagadását jelenti - és így Szelényi és Varga platformja nem áll távol egymástól -, hanem csupán azt, hogy a rövid távú gondolkodást és ezen belül a konzumhedonizmust bírálók által diagnosztizált hiánybetegségében a társadalmat juttassuk újra életmentő $v i$ taminokhoz.

\section{HARMADIK METAFORA: VÉDŐHÁLÓ VAGY FÜGGÖÁGY}

Mint fentebb jeleztük, Lakoff-polémiájával itt a junior szerző veszi át a vezérszólamot. Éspedig a Trump-győzelem utáni sokkhatás alatt gyötrődő Obama elnök szavaival: „Néha azt gondolom, talán tíz-húsz évvel korábban érkeztem [...] Talán az emberek vissza akarnak térni törzseikhez." (Baker, 2018). Mintha itt a nyugati balliberális elit évtizedek óta szövögetett messianisztikus narratívája foszlott volna szét, amely szerint a balliberális tanok fényénél az emberek felszámolnak minden elnyomó struktúrát, amit a heteroszexuális-keresztény-fehér férfiak hoztak létre. Az Egyesült Államokban e haladás politikáját a Demokarta Párt képviseli. Az első színes bőrü, a politikai spektrum bal széléhez húzó Obama két ciklusra nyúló elnöksége e messianisztikus időket volt hivatott bevezetni. Trump győzelme „történelmi anomália”, amire a Lakoff nyelvészprofesszor, az amerikai baloldal teoretikai kampánygéniusza által kidolgozott politikai metaforaelmélet próbált magyarázatot adni. Eszerint a politikai élet szereplői és résztvevői metaforákban beszélnek, gondolkodnak, és értelmezik a világot (Bodor, 2012; Lakoff, 2002; Varga, 2013). Például az amerikai konzervatívok alapmetaforája az „erkölcsi erő", amely keretét adja azoknak az attitüdöknek, amelyeket a konzervatívok a

\footnotetext{
${ }^{4}$ A kifejezést Turgonyi Zoltán (2014) tanulmányából vettük, amit e-mail-üzenetben a következő megjegyzéssel bocsájtott rendelkezésünkre: „Ami a »javított liberalizmust« illeti, ennek alapvetése az, hogy az erkölcsnek egyszerre feladata az egyéneket megvédeni attól, hogy mások károkat okozzanak nekik, másrészt a társadalom fennmaradását biztosítani. A liberalizmus hatására e második funkció háttérbe szorult, csak az egyén jogait védik. A liberális társadalomnak is szüksége van önmaga újratermelésére, de az államnak a mai liberalizmus uralkodó formája szerint »nem illik« támogatnia a hagyományos családot, már ez is »diszkriminálná« a másképpen élőket. Ám a liberálisok között is voltak, akik fölfigyeltek e problémára (például Walter Lippman vagy Raymond Aron), s ezért az e korrekció sikere esetén kialakuló társadalmat is lehet még liberálisnak nevezni."
} 
gondoskodó állam szociális programjaival szemben alakítanak ki. Így például az állami segélyek rendszere (munkanélküli segély, ingyenes ételjegyek) immorális, mivel az emberek erkölcsi erőből fakadó képességeit ássa alá, úgymint az öngondoskodást, a szorgalmat vagy az önfegyelmet. Ezzel szemben a liberálisok kulcsmetaforája a „moralitás mint gondoskodás”, amely az együttérzést és a szükséget szenvedők segítését hangsúlyozza. Beleértve e körbe újabban a migránsokat is.

Lakoff elemélete szerint mindkét félnek koherens értékeik vannak a családdal kapcsolatban. A konzervatív családi értékkomplexet Strict-Father Modelnek (szigorú apa) nevezi. „A szigorú apa kötelessége, hogy oltalmazza családját a Gonosz külső és belső formáival szemben. Ő testesíti meg azokat az értékeket, amelyek segítik az embert a boldogulásban. Az apa kötelessége, hogy elmondja gyermekeinek, mi a jó és mi a rossz. A szigorú apa számára a szigorúság a »kemény szeretet « (tough love) kifejezése.” Ezzel szemben áll a családi értékek liberális modellje, a gondoskodó szülő (Nurturant Parent): „A világ tele van rossz dolgokkal, amelyek károsíthatják a gyermeket, és a gondoskodó szülő kötelessége, hogy olyan gyermekkort biztosítson neki, amelyben megtanulja fejleszteni képzelőerejét, és csak egyszerủen jól érzi magát. A család olyan közösség, amelyben a gyermekeknek másokkal való együttérzésből fakadó felelősségeik vannak."

A két családi értékmodellt a nemzet mint család (the nation-as-family) metafora teszi a politikai retorika látens kódrendszerévé. Lakoff szerint a konzervatívok bátrabban alkalmazzák saját metaforáikat. Phil Gramm republikánus szenátor például egy egyszerủ metaforával ásta alá a demokraták által mindmáig ünnepelt New Deal során kifeszített „,szociális védőháló” reputációját. Gramm a védőhálóra mint kifeszített „függőágyra” utalt, amely szerinte megfosztja Amerikát erényeitől. A függőágy metafora egyéb konzervatív metaforákat aktiválva erőteljes, értékalapú negatív reakciót vált ki a választókból. Relevanciát nyer az erkölcsi erö metafora: aki a függőágyban hever, vagyis állami segélyben részesül, alapvetően lusta, nem áll szándékában dolgozni, nincs erkölcsi tartása. A konzervatív érvek és kampányüzenetek erőteljesebben rezonálnak a választók értékeivel, mint az értékkomponenst ritkábban tartalmazó liberális üzenetek. A Lakoff instrukcióit láthatóan megfogadó Obama a kultúrharc frontján ugyan sikereket ért el (például az egynemüek házasságának legalizálása, az egészségügyi védőháló kiterjesztése: „Obamacare”), ám Trump váratlan győzelme véget vetett a Demokrata Párt messianisztikus regnálásának.

Már e rövid vázlat is megsejteti a párhuzamot a korábbi magyar munkanélküli segélyrendszert felváltó munkaalapú társadalom és a szociális „védőháló” Phil Gramm szenátor által „függőággyá” karikírozása között. (Főleg azokkal az érzelmi hatásokkal, amelyeket a napi munkába járás helyett otthon ülö és segélyt váró édesapa képe, illetve a teljes foglalkoztatottság sikeres közelítésének kontrasztja vált ki.) Ám itt leplezhetjük le Lakoff tévedését is. Az amerikai baloldal problémája ugyanis voltaképp nem az, hogy nem alkalmazzák értékalapú meta- 
foráikat, hanem a World Values Survey által regisztrált értékrendi folyamatok adatai tanúsítják, hogy a nyugati világban tapasztalt attitüdinális balra tolódás nem feltétlenül lesz képes felülkerekedni az eredeti keresztény Nyugat konzervatív narratívájával szemben (Inglehart et al., 2014; Bodor-Varga, 2015). Az értékek mélystruktúráját feltáró gyermeknevelési adatok szerint ugyanis 1995 és 2011 között az amerikai társadalmat kétirányú mozgás jellemezte a tolerancia (mint elsődleges „gondoskodó szülő” érték) és a kemény munka (mint alapvető „,szigorú apa" érték) alkotta kétdimenziós értéktérben. Míg az amerikai társadalom egésze elmozdulást mutatott a kemény munka fontosságának irányában, feltủnő polarizációs trend jelent meg a Demokarta és Republikánus párt támogatóinak körében. Míg a demokraták a tolerancia hangsúlyozásának irányában mozdultak el, addig a republikánusok körében a toleranciát mint fontos értéket választók aránya határozottan megcsappant (60\% alá esett), és a kemény munkát választók aránya 53\%-ról 76\%-ra (!) nőtt. (Lásd az ábrát, ahol világosan látszik, hogy a vizsgált másfél évtized alatt a demokraták (D) kis elmozdulásokkal nagyjából egy és ugyanazon tolerancia-érték térfelén „topogtak”, addig a republikánusok (R) innen szinte „nyílegyenesen” távolodtak a kemény munka-érték irányába.)

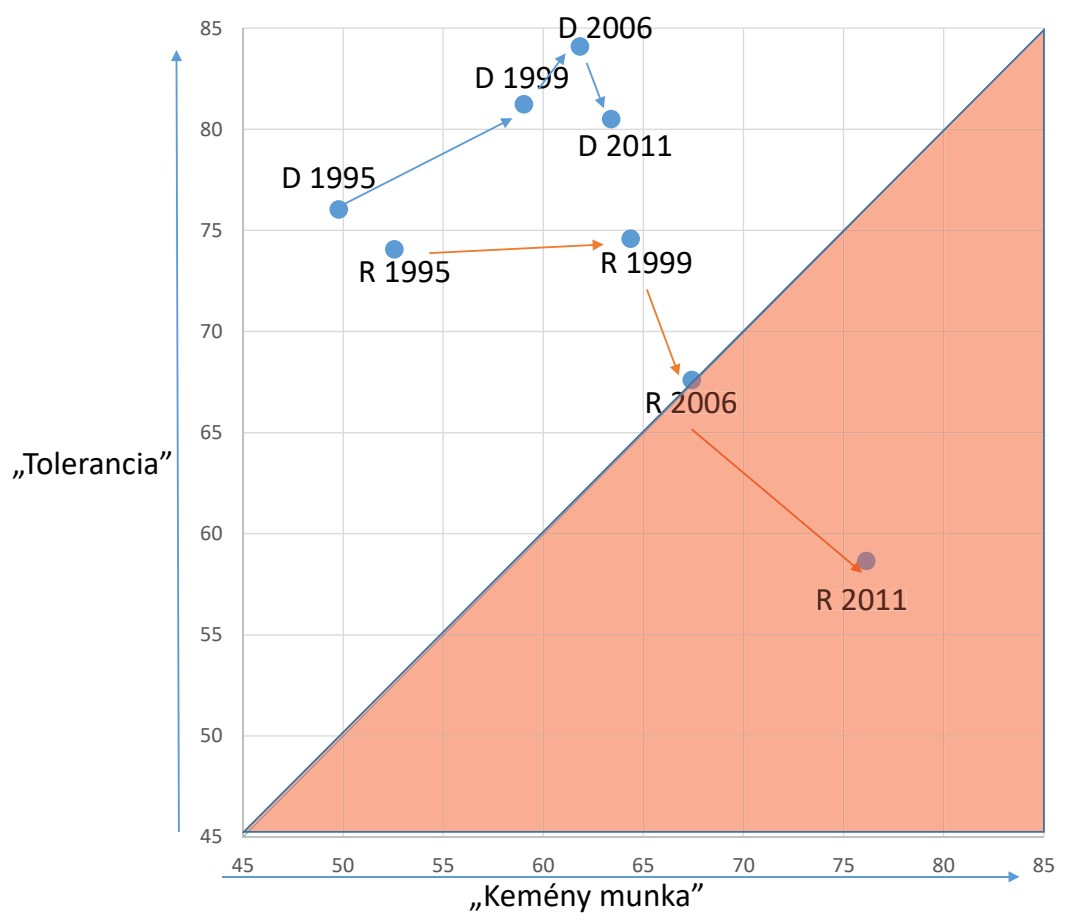

Bodor Tamás szerkesztése a World Values Survey adatok felhasználásával

(Inglehart et al., 2014) 
A „Trump-anomália” tehát, szemben Lakoff elképzelésével, nem magyarázható egyszerü kampánykommunikációs melléfogással. Liberális szempontból a probléma inkább az lehet, hogy a túlélést a gonosz erők által uralt világban lehetővé tevő szigorú apa típusú értékek a baloldali történelmi narratíva ívét megtörő vitalitást mutatnak. A felvilágosult Nyugat polgárainak legalábbis egy jelentős része, Obama szavait idézve, talán valóban vissza akar térni „törzseihez”, meg akarja védeni nemzeti közösségeit, és visszautasítja, hogy feloldódjon a balliberális elit által rájuk kényszerített globális neomarxista-posztmodern utópiában.

\section{NEGYEDIK METAFORA: GYÜMÖLCSÖSTÁL VAGY TURMIXOLT GYÜMÖLCSLÉ}

Ide először egy szintén (legalább félig) mitikus metafora kínálkozott: a trójai faló, tekintettel arra, a már Homérosznál is feltünő körülményre, hogy a várvédők egyenesen lebontották a kaput körülvevö falrészeket, hogy belülre tudják vontatni végzetük eszközét, amihez látványosan passzolhat a Willkommenskultur társadalmi közérzettel szembeni erőltetése. Ez azonban nem illeszkedett eszmélődésünkhöz, amely a harcos képek helyett a közös problémamegoldás ambíciójával próbál érvelni, ezért adtunk elsőbbséget e békésebb metaforának. Így végezetül tehát az értékszociológia egyik legfrissebb teljesítményeként tisztázási kísérletet teszünk a világmigráció értelmezéséről és megoldási irányzatairól.

Tévedés ne essék, az értékszociológiai közelítés is valósnak tartja azt a korértelmezést, hogy az országok, sőt földrészek történelmileg kialakult gazdasági különbségeinek a globalizációs egymásra hatás és ennek kommunikációs szupertechnológiája (műholdak) révén épp a 21. században érik be egy kiegyenlitődési dinamikája. Ám az sem kerüli el a figyelmét, hogy ez a dinamika egy olyan ideológiával került szövetségbe, amely ama valláskritikus történelmi eszmeáramlatok örököse, amelyek pozitívumnak tartják a hagyományos eszme- és intézményrendszerek gyengülését (legalábbis a kereszténység vonatkozásában).

$S$ itt térünk vissza az értékrendszerek Hofstede-féle „digitális világtérképére”, immár egy másik tartalmi metszetében, ahol a „hosszúsági és szélességi körök” az ,individualizmus vs. kollektivizmus”, illetve „maszkulin vs. feminin” kultúratípusok dimenziói találhatók. Hofstede már egy évtizeddel ezelőtt megállapította, hogy a migráció fö tendenciájában a kollektivista és maszkulin kultúrák felől áramlik az individualistább és femininebb nyugati kultúratípusba. Ez pedig olyan behatolási manővert jelenthet, amelynek borítékolható eredménye a hanyatló keresztény hit és gyakorlat „lágy” közegében egy azonnali arrogáns helykövetelés, pár generáción belül pedig az uralom átvétele volna.

Ezért érezzük ide alkalmazhatónak a rendszerváltás kormányának oktatási államtitkára, Kálmán Attila által a keresztény felekezetek közötti viszonyra felállított eme metaforát: míg a katonakultúrák katonakorú férfiainak milliós nagy- 
ságrendü tartós beözönlése a történelmi fejlődésében már jelentős individualista és feminin értékeket kivívott európai és atlanti kultúratípusba ezek világnézeti és magatartási mintázatainak zavaros gyümölcslébe való turmixolását jelentené, addig a saját földrészeiken maradó kultúrák épségét és szépségét az étvágygerjesztő gyümölcsöstál illusztrálja. Ennek logisztikai megfelelője az, hogy inkább oda kell vinni a gazdagabb civilizáció segítségét, ahol a szegénység és háborúság dúl, semmint a bajt a terrorizmus és antiszemitizmus, párhuzamos társadalmak és egyre kevésbé letagadható no-go zónák formájában ide importálni. Ez lehetne a bolygónk természettudományi-fizikai megmentésével azonos nagyságrendü társadalmi-humán megastratégia.

És itt még a turmixpárti nézetekkel való polemizálás helyett inkább egy baráti ad hominem érvnek adnánk hangot. Miután ugyanis a témában kompetens - menekülttábor- és lepratelep-alapító - Henri Boulad a párbeszéd szempontjából „hatféle iszlámot” különböztet meg, és ezek közül azt a liberális irányzatot tartja a legpozitívabbnak, amely kisebbségként áll szemben a politikai-vallási világuralomra törő domináns válfajokkal, ez a szakértői áttekintése azt sugallja, hogy a világ felvilágosult liberálisainak az itteni társadalom védekezési reflexeinek gyengítése helyett inkább ott kellene csillapítaniuk a támadókészséget, ahol a nyílt vagy rejtett (de nem kevésbé eltökélt) turmixolási indulat erjed.

A témához immár nemzetközileg érezhető tisztulási szakaszában kapcsolódik Szelényi Ivánnak szintén tanítványával, Mihályi Péterrel írt tanulmánya (2018), melyben a szerzők ,a nemzetállamok ellenforradalmaként” aposztrofálják a nemzeti szuverenitások hanyatlásának ellenszegülő globalizációkritikát. Nos, a két dolgozat szenior szerzői egymás közötti folyamatos e-mail háttérvitájukban e legújabb nézetütközésüket a következőképp könyvelték el. Szelényi: „Megtanultuk, hogyan kell egyetértenünk abban, hogy miben nem értünk egyet." Varga pedig arra emlékeztetett, hogy hiszen már egyetértésre is jutottak abban, hogy ezt az emberiség-léptékü transzformációt az ENSZ most hübelebalázs módjára gondolja áthajthatónak (!). Majd kompromisszumként kínálta fel: ilyen értelemben a „nemzetállami ellenforradalom” netán tekinthető akár „fontolva haladásnak” is. A turmixolt gyümölcslével szembeállított gyümölcsöstál metafora pedig mintha tényleg józanabb stratégiára utalna, mint a migráns-költségvetés megháromszorozását tervező EU-politika, amely a magyar történelmi tudatban Budavára 1541-es békés elfoglalását idézi fel a muszlim katonakultúra által.

\section{IRODALOM}

Baker, P. (2018): How Trump's Election Shook Obama: 'What if We Were Wrong?'. New York Times, 30 May 2018. https://www.nytimes.com/2018/05/30/us/politics/obama-reaction-trump-election-benjamin-rhodes.html

Bell, D. (1976, 1996): The Cultural Contradictions of Capitalism. Basic Books 
Bodor T. (2012). The Deep Structure of Conservative and Liberal Political Attitudes: An Empirical Exploration of Lakoff's Strict Father and Nurturant Parent Models of Morality. Paper Presented at the Annual conference of the Midwest Political Science Association, April, 12-15. Chicago, Illinois

Bodor T. (2013): Amerikai értékek Lakoff és a World Value Survey szembesítésében. In: Varga K. (2013): Fénykör: Értékszociológia, nemzetstratégia. Budapest: Akadémiai Kiadó

Bodor T. - Varga K. (2015): The Tale of Two Regions: The Fragile Idea of a Sovereign Society. Paper Presented at the Annual Conference of the World Association for Public Opinion Research, Buenos Aires, Argentina

Boulad, H. (2009): Az iszlám a misztika, a fundamentalizmus és a modern kor feszültségében. Budapest: Kairosz Kiadó

Hankiss E. - Manchin R. - Füstös L. et al. (1982): Continuity and Break: The Analysus of the Value System of Hungarian Society 1930-1978. Budapest: MTA Szociológiai Intézet

Hegedűs A. (1988): A történelem és a hatalom igézetében. Budapest: Kossuth Kiadó

Hofstede, G. - Hofstede, G. J. (2008): Kultúrák és szervezetek: Az elme szoftvere. (ford. Oláhné Szentessy É.) Pécs: VHE Kft. (eredetileg: Cultures and Organizations. Software of the Mind. McGraw-Hill, 2005, https://e-edu.nbu.bg/mod/resource/view.php?id=557036

Inglehart, R. et al. (eds.): (2014): World Values Survey: All Rounds - Country-Pooled Datafile Version. Madrid: JD Systems Institute, http://www.worldvaluessurvey.org/WVSDocumentationWVL.jsp

Knauer, P. (2011): Christus in den Religionen - Interiorismus, Dialog, Pluralismus. In: Polykarp Ulin Agan SVD (Hrsg.): Pluralistische Religionstheologie und Mission. Nettetal: Steiler Verlag, 81-106. http://peter-knauer.de/ChristusinReligionen.doc

Kulin F. (1994): A tét. Interjúk, esszék a nemzetről és a rendszerváltozásról. Budapest, Bagolyvár Kiadó

Kulin F. (2008): A harmadik út fénykörében: Megjegyzések Varga Károly könyvéhez. In: Készenlét. (Kölcsey füzetek 20.) Budapest: Argumentum Kiadó

Kulin F. (2017): A szociológia esélyei. Magyar Müvészet, 2017. március, http://www.magyar-muveszet.hu/upload/userfiles/2/publications/201801/pdf/MM2017_lbelivek_kepnelkul_teljes.pdf

Lakoff, G. (2002): Moral Poilitics - How Liberals and Conservatives Think. The University of Chicago Press

Lakoff, G. (2006): Ne gondolj a fehér elefántra! Budapest: Napvilág Kiadó

Lakoff, G. (2009): The Political Mind. Penguin Books

Lakoff, G. (2016): Understanding Trump. July 23, in Political 2 Comments, https://georgelakoff. com/2016/07/23/understanding-trump-2/

Merton, R. K. (1980): Társadalomelmélet és társadalmi struktúra. Budapest: Gondolat Kiadó

Mihályi P. - Szelényi I. (2018): A nemzetállamok ellenforradalma. Élet és Irodalom, június 1. https://www.es.hu/cikk/2018-06-01/mihalyi-peter-szelenyi-ivan/a-nemzetallamok-ellenforradalma.html

Morris, C. (1956): Varieties of Human Value. Chicago: The University of Chicago Press, https:// archive.org/details/varietiesofhuman010598mbp/page/n8

MSZMP KB Kulturális és Elméleti Munkaközössége (1966): Az irodalom, a müvészetek és a társadalmi ízlés. Társadalmi Szemle, július-augusztus.

Simirenko, A. (ed.) (1966): Soviet Sociology: Historical Antecedens and Current Appraisal. Chicago: Quadrangle Books

Szelényi I. (2014): Fénykör. Magyar Tudomány, 175, 3, 376. http://www.matud.iif.hu/2014/03/18.htm

Szelényi I. (2018): Társadalomtudomány három „rendszerben”. A Wesley János Lelkészképző Főiskolán elhangzott előadás 
Turgonyi Z. (2014): A természetjog érvényesülése a demokratikus társadalmakban. Magyar Bioetikai Szemle, XX, 3, 119.

Varga K. (1965): Értékelmélet és empirikus értékvizsgálat. Valóság, 10, 99-105.

Varga K. (1968): Magyar egyetemi hallgatók életfelfogása: nemzetközi összehasonlitás. (Szociológiai tanulmányok 5) Budapest: Akadémiai Kiadó

Varga K. (1970): The View of Life of Hungarian Students: An International Comparison. Journal of Cross-Cultural Psychology, 1, 2, 169-176.

Varga K. (1973): Marital Cohesion as Reflected in Time Budgets. In: Szalai A. - Converse, P. E. Feldheim, P. et al. (eds.): The Use of Time: Daily Activities of Urban and Suburban Populations in Twelve Countries. Hague: Mouton, 357-375.

Varga K. (1986, 1988): Az emberi és szervezeti eröforrás fejlesztése. (Szervezeti akciókutatások eredményei és tanulságai) Budapest: Akadémiai Kiadó

Varga K. (2001): „Hegedűs a te(1)jesember”. In: Rozgonyi T. - Zsille Z.: Búcsú Hegedűs Andrástól. Budapest: Osiris Kiadó

Varga K. (2009): Időhorizontok harca. Adalék a gazdasági világválság értelmezéséhez. Magyar Tudomány, 170, 5, 638-639. http://www.matud.iif.hu/2009/09maj/15.htm

Varga K. (2013, 2014): Fénykör. Értékszociológia, nemzetstratégia. (Geert Hofstede elöszavával, Függelékében: Bakacsi Gy., Bodor T., Sághi T. kutatási beszámolóival.) (A 2003-as Értékek fénykörében c. könyv tíz évvel későbbi, bővített és aktualizált kiadása) Budapest: Akadémiai Kiadó

Varga K. (2015): Evolúciós hipotézisek és alkalmazásuk a migrációra. JURA, 21, 2. https://jura. ajk.pte.hu/JURA_2015_2.pdf

Varga K. (2016): Spiritualitás és migráció. Magyar Tudomány, 177, 9, 1118-1129. http://www.matud.iif.hu/2016/09/12.htm

Varga K. (2017): Iszlám pokol és szinkretizmus: Az ábrahámi vallások Istenének ,árnyoldala” és „evolúciója”. Valóság, február, http://epa.oszk.hu/02900/02924/00050/pdf/EPA02924_valosag_2017_02_005-018.pdf

Varga K. (2017): Relativizmus és fundamentalizmus között: Az ökumené paradoxonjának metakommunikatív feloldási kísérlete. Jel-Kép, 3. DOI: 10.20520/JEL-KEP.2017.3.79, http://communicatio.hu/jelkep/2017/3/JelKep_2017_3_Varga_Karoly.pdf

Varga K. (2018): Az értékszociológia teljesítménye a tört-mat „tabutörésétöl” a liberalizmus „,kijavitásáig”. A Wesley János Lelkészképző Főiskolán elhangzott előadás. 